\title{
Keefektifan Media Video terhadap Minat dan Hasil Belajar Matematika Kelas III SD
}

\author{
Diah Meyta Nur Cholida*, Goenawan Roebyanto, Erif Ahdhianto \\ Universitas Negeri Malang, Jl. Semarang No. 5 Malang, Jawa Timur, Indonesia \\ *Penulis korespondensi, Surel: meyta216@gmail.com
}

Paper received: 5-7-2021; revised: 23-7-2021; accepted: 30-7-2021

\begin{abstract}
This study aims to find out about the effectiveness of video media on the interests and results of learning mathematics. This research was only conducted in grade III A of SDN Bumiayu 2. There are two variables studied, namely students' interest and learning outcomes in mathematics subjects. This study uses a type of Pre-Experimental research using One Group Pretest-Posttest Design. A sample of 27 students was designated as experimental classes. The results of the study showed that there are differences before being treated and after being treated in the form of learning video media. This is seen by the Paired Sample T Test with a significance value of 0.000 less than 0.05 . In the test of effectiveness by using the test $\mathrm{N}$-Gain Score on learning interests is 0.683 , while in the study results are worth 0.42 . From the data, there is an effectiveness and video media to the interests and learning outcomes of grade III students at SDN Bumiayu 2 in the moderate category.
\end{abstract}

Keywords: effectiveness; video media; learning interests; learning outcomes

\begin{abstract}
Abstrak
Penelitian ini bertujuan untuk mengetahui mengenai keefektifan media video terhadap minat dan hasil belajar matematika. Penelitian ini hanya dilakukan di kelas III A SDN Bumiayu 2. Terdapat dua variabel yang diteliti yaitu minat dan hasil belajar siswa pada mata pelajaran matematika. penelitian ini menggunakan jenis penelitian Pre-Experimental dengan menggunakan One Group Pretest-Posttest Design. Jumlah sampel sebanyak 27 siswa yang ditetapkan sebagai kelas eksperimen. Pada hasil penelitian menunjukkan bahwa terdapat perbedaan sebelum diberi perlakuan dan sesudah diberi perlakuan berupa media video pembelajaran. Hal ini dilihat dengan uji Paired Sample T Test dengan nilai signifikansi 0,000 kurang dari 0,05. Pada uji keefektifan dengan menggunakan uji $N$-Gain Score pada minat belajar yakni 0,683, sedangkan pada hasil belajar bernilai 0,42. Dari data tersebut maka terdapat keefektifan media video terhadap minat dan hasil belajar siswa kelas III SDN Bumiayu 2 dalam kategori sedang.
\end{abstract}

Kata kunci: keefektifan; media video; minat belajar; hasil belajar

\section{Pendahuluan}

Pendidikan merupakan bagian yang penting dari suatu proses pembangunan suatu negara, karena tidak mungkin tanpa dukungan pendidikan, perkembangan suatu negara dapat berkembang secara normal. Sependapat dengan Hakim (2016) bahwa pendidikan merupakan salah satu syarat mutlak bagi perkembangan pembangunan bangsa Indonesia, karena pondasi pembangunan strategis adalah pendidikan. Pendidikan yang efektif adalah pendidikan yang memungkinkan siswa dapat belajar secara menyenangkan dan tujuan sesuai dengan yang diharapkan. Oleh karena itu guru dituntut untuk dapat meningkatkan keefektifan pembelajaran agar berguna bagi siswa (Asyari, 2016).

Keterampilan mengajar guru sangat penting dikarenakan guru yang profesional harus memiliki kemampuan dan keahlian dalam bidang keguruan serta mampu menjalankan tugas maupun fungsinya. Menurut Amir (2016), guru merupakan komponen pendidikan yang 
berperan penting dalam keberhasilan pada pembelajaran matematika. Namun kenyataannya siswa seringkali gagal dalam mengikuti proses pembelajaran matematika dikarenakan siswa menganggap matematika membosankan untuk dipelajari seperti penjelasan guru yang susah untuk dipahami dan guru kurang memperhatikan kesesuaian media dalam proses belajar. Hal tersebut menyebabkan penurunan konsentrasi siswa yang berakibat tujuan pembelajaran tidak tercapai.

Pelajaran matematika harus diusahakan tidak membosankan dan dapat menarik minat belajar siswa. Menurut Riwahyudin (2015), siswa yang tertarik dengan kegiatan belajar akan berusaha lebih keras dibandingkan dengan siswa yang tidak terlalu tertarik untuk belajar. Minat belajar sangat berpengaruh besar terhadap hasil belajar, karena apabila bahan yang dipelajari tidak sesuai dengan minat maka siswa tidak akan belajar dengan baik. Ketika seorang guru menguasai teori belajar, menciptakan suasana kelas yang menyenangkan dan merangsang siswa bersemangat belajar, memberikan penguatan verbal dan non verbal, menyegarkan kelas ketika siswa mulai lelah juga penggunaan media pembelajaran dapat meningkatkan semangat belajar bagi siswa karena pada proses belajar mengajar guru akan menghadapi karakteristik siswa yang beragam (Salsabila \& Puspitasari, 2020).

Penggunaan media pada pembelajaran berdampak besar bagi keberhasilan suatu pembelajaran. Sesuai dengan penggunaannya, materi dan jenjang siswa harus disesuaikan oleh guru. Oleh karena itu guru harus menyesuaikan media yang cocok dan sesuai untuk siswa yang akan diajar. Pemilihan media yang digunakan dalam pembelajaran matematika harus mempertimbangkan beberapa hal, diantaranya: (1) media harus mampu memberikan dampak yang positif bagi siswa melalui media pembelajaran yang dapat meningkatkan minat, motivasi, dan hasil belajar siswa; (2) dalam menggunakan media hendaknya membimbing siswa dalam menghubungkan konsep yang sudah dimiliki dengan pengetahuan yang baru dipelajari; (3) media dapat mengaktifkan siswa dalam memberikan umpan balik pembelajaran (Ulya, 2017).

Penggunaan media pembelajaran matematika dalam bentuk video memungkinkan untuk digunakan dalam berbagai situasi baik di rumah maupun di sekolah. Menurut Wisada \& Sudarma (2019), dengan adanya video pembelajaran siswa dapat meningkatkan minat belajar, memahami gambaran secara nyata, dan menjadikan siswa lebih mandiri dalam proses pembelajaran. pada proses pembelajaran kriteria pemilihan media pembelajaran yang terpenting disesuaikan dengan tujuan pembelajaran yang ingin dicapai, karena bertujuan untuk membantu guru mempermudah siswa dalam memahami pembelajaran secara efektif. Peran video di masa pandemi merupakan salah satu solusi untuk membuat siswa memahami materi pelajaran dengan baik. Media video dapat menggantikan guru ketika siswa ingin mengulang kembali materi matematika yang telah dipelajari di kelas. Video juga dapat mengatasi keterbatasan waktu, ruang siswa, maupun guru.

Berdasarkan observasi di SDN Bumiayu 2, peneliti menemukan permasalahan mengenai pembelajaran matematika di kelas diantaranya selama pembelajaran berlangsung guru menggunakan metode konvensional dan masih belum menggunakan media pembelajaran yang dapat menarik perhatian siswa dan menyebabkan siswa terlihat jenuh dan kurang tertarik mengikuti kegiatan pembelajaran.

\section{Metode}

Metode penelitian ini adalah eksperimen dengan desain penelitian One Group Pretest Posttest Design. Terdapat pretest sebelum diberikan perlakuan, dan posttest sesudah diberikan 
perlakuan. Penelitian ini menggunakan teknik Simple Random Sampling. Peneliti menetapkan sampel sebanyak 27 siswa di kelas III A sebagai kelas eksperimen. Pengumpulan data terdiri dari observasi, dokumentasi, tes, dan angket. Untuk tes dan angket terdiri dari pretest dan posttest. Pada tes menggunakan pilihan ganda yang berjumlah 15 soal dengan 3 opsi jawaban yang mengukur variabel hasil belajar siswa dengan skala 1-100. Untuk angket menggunakan skala likert berupa pernyataan positif dan negatif.

Analisis data menggunakan uji prasyarat analisis yaitu uji normalitas dan homogenitas. Pada uji normalitas digunakan untuk menentukan apakah sampel berdistribusi normal atau tidak, sedangkan untuk uji homogenitas mengetahui bahwa suatu sampel bersifat homogen. Untuk menguji suatu asumsi menggunakan uji hipotesis dan apabila menguji keefektifan menggunakan uji $N$-Gain Score.

\section{Hasil dan Pembahasan}

\subsection{Hasil}

Pada penelitian ini menggunakan pre-experimental yang dilakukan untuk melihat keefektifan media video terhadap minat dan hasil belajar matematika. Media video pembelajaran dilakukan di kelas III SDN Bumiayu 2 dengan sampel yang berjumlah 27 siswa. Peneliti melaksanakan pembelajaran dengan memberikan pretest pada kelas III, kemudian melakukan pembelajaran dengan menggunakan video pembelajaran dan selanjutnya pemberian posttest.

\subsubsection{Data Minat Belajar}

Analisis data minat belajar yang berjumlah 20 butir pernyataan. Pretest diberikan sebelum diberikan perlakuan, kemudian posttest diberikan setelah diberikan perlakuan. Data minat belajar siswa dapat dilihat pada Tabel 1.

Tabel 1. Data Minat Belajar Siswa

\begin{tabular}{lcc}
\hline \multicolumn{1}{c}{ Data } & Pretest & Posttest \\
\hline Jumlah sampel & 27 & 27 \\
Nilai minimum & 38 & 55 \\
Nilai maksimum & 63 & 70 \\
Mean & 49,407 & 63,629 \\
Varians & 38,789 & 15,088 \\
Standar Deviasi & 6,228 & 3,884 \\
\hline
\end{tabular}

Berdasarkan tabel di atas jumlah sampel yakni 27 siswa. Dari data di atas diketahui bahwa pretest nilai minimum 38 dan nilai maksimum diperoleh 63. Untuk mean 49,407 dan pada varians 38,789 . Sedangkan pada posttest untuk nilai minimum diperoleh 55, sedangkan untuk nilai maksimum diperoleh 70, pada mean 63,629 dan varians 15,088.

\subsubsection{Data Hasil Belajar}

Analisis data hasil belajar dengan menggunakan soal pilihan ganda dengan 15 soal pretest dan 15 soal posttest. Data hasil belajar dapat dilihat pada Tabel 2. 
Tabel 2. Data Hasil Belajar Siswa

\begin{tabular}{lcc}
\hline \multicolumn{1}{c}{ Data } & Pretest & Posttest \\
\hline Jumlah sampel & 27 & 27 \\
Nilai minimum & 30 & 60 \\
Nilai maksimum & 87 & 100 \\
Mean & 59,78 & 76,29 \\
Varians & 227,795 & 122,063 \\
Standar Deviasi & 15,092 & 11,048 \\
\hline
\end{tabular}

Berdasarkan tabel di atas jumlah sampel penelitian 27 siswa. Dari data di atas diketahui bahwa nilai minimum pada pertest 30 dan nilai maksimum 87 . Untuk mean pada pretest 59,78 dan varians 227,795. Sedangkan pada posttest nilai minimum diperoleh 60 dan nilai maksimum sebesar 100. Nilai dari mean yaitu 76,29 dan varians 122,063.

\subsubsection{Analisis Data}

\subsubsection{Uji Normalitas}

Uji normalitas digunakan untuk mengetahui data berdistribusi normal atau tidak dengan membandingkan taraf signifikansi yaitu 0,05 . Apabila taraf signifikansinya lebih dari 0,05 maka data berdistribusi normal.

\subsection{Uji Normalitas Minat Belajar Siswa}

Pada pengujian normalitas data minat belajar dilakukan dengan menggunakan aplikasi SPSS. Pada uji normalitas menggunakan Shapiro Wilk. Berikut merupakan Tabel 3. hasil perhitungan uji normalitas.

Tabel 3. Uji Normalitas Minat Belajar

\begin{tabular}{lccc}
\hline & Statistic & df & Sig. \\
\hline Pretest & 0,952 & 27 & 0,242 \\
Posttest & 0,950 & 27 & 0,215 \\
\hline
\end{tabular}

Berdasarkan tabel di atas menunjukkan hasil uji normalitas untuk pretest 0,242 $>0,05$ dan untuk posttest sebesar 0,215 >0,05. Dikarenakan pada pretest dan posttest nilai signifikansinya lebih dari 0,05 maka data berdistribusi normal.

\subsection{Uji Normalitas Hasil Belajar Siswa}

Pada pengujian normalitas data hasil belajar dilakukan dengan menggunakan aplikasi SPSS. Pada uji normalitas menggunakan Shapiro Wilk. Berikut merupakan Tabel 4. hasil perhitungan uji normalitas.

Tabel 4. Uji Normalitas Hasil Belajar

\begin{tabular}{lccc}
\hline & Statistic & df & Sig. \\
\hline Pretest & 0,959 & 27 & 0,349 \\
Posttest & 0,934 & 27 & 0,085 \\
\hline
\end{tabular}


Berdasarkan tabel di atas menunjukkan hasil uji normalitas untuk pretest 0,349 >0,05 dan untuk posttest sebesar 0,085 > 0,05. Dikarenakan pada pretest dan posttest nilai signifikansinya lebih dari 0,05 maka data berdistribusi normal.

\subsubsection{Uji Homogenitas}

Setelah melakukan uji normalitas didapatkan hasil bahwa data berdistribusi normal dilakukan uji homogenitas untuk mengetahui bahwa suatu sampel bersifat homogen. Pada pengujian homogenitas digunakan untuk mengetahui data homogen atau tidak dengan membandingkan taraf signifikansi dengan 0,05. Data dikatakan homogen apabila taraf signifikansinya lebih dari 0,05.

\subsection{Uji Homogenitas Minat Belajar Siswa}

Pada pengujian homogenitas menggunakan aplikasi SPSS 25. Berikut ini merupakan Tabel 5. hasil perhitungan uji homogenitas.

Tabel 5. Uji Homogenitas Minat Belajar

\begin{tabular}{lcrrc}
\hline & Levene Statistic & df1 & df2 & Sig \\
\hline Based on Mean & 2,184 & 1 & 52 & 0,145 \\
\hline
\end{tabular}

Berdasarkan tabel di atas nilai signifikansinya 0,145. Hal ini berarti 0,145 $>0,05$. Berdasarkan nilai signifikansi dapat dinyatakan bahwa sampel pada penelitian ini bersifat homogen karena nilai signifikansi lebih dari 0,05.

\subsection{Uji Homogenitas Hasil Belajar Siswa}

Pada pengujian homogenitas menggunakan aplikasi SPSS 25. Berikut ini merupakan Tabel 6. hasil perhitungan uji homogenitas.

Tabel 6. Uji Homogenitas Hasil Belajar

\begin{tabular}{lcccc}
\hline & Levene Statistic & df1 & df 2 & Sig \\
\hline Based on Mean & 2,147 & 1 & 52 & 0,149 \\
\hline
\end{tabular}

Berdasarkan tabel di atas nilai signifikansinya 0,149. Hal ini berarti 0,149 $>0,05$. Berdasarkan nilai signifikansi dapat dinyatakan bahwa sampel pada penelitian ini bersifat homogen karena nilai signifikansi lebih dari 0,05.

\subsubsection{Uji Hipotesis}

Pada penelitian ini bertujuan untuk pengujian hipotesis nol atau hipotesis yang akan diuji. Jika nilai signifikansinya kurang dari 0,05 maka dapat dinyatakan bahwa $\mathrm{H}_{\mathrm{a}}$ diterima dan $\mathrm{H}_{0}$ ditolak. 


\subsection{Uji Hipotesis Minat Belajar Siswa}

Uji hipotesis pada penelitian ini menggunakan uji Paired Samples Test. Berikut merupakan Tabel 7 hasil perhitungan uji hipotesis.

Tabel 7. Uji Paired Sampel Test Minat Belajar

\begin{tabular}{|c|c|c|c|c|c|c|c|c|}
\hline & & & & $\begin{array}{l}95 \% \text { Confid } \\
\text { Interval of t } \\
\text { Difference }\end{array}$ & $\begin{array}{l}\text { nce } \\
\text { e }\end{array}$ & & & \\
\hline & Mean & $\begin{array}{c}\text { Std. } \\
\text { Deviasi }\end{array}$ & $\begin{array}{c}\text { Std. Error } \\
\text { Mean }\end{array}$ & Lower & Upper & 1 & df & $\begin{array}{l}\text { Sig. (2- } \\
\text { tailed) }\end{array}$ \\
\hline $\begin{array}{l}\text { Pretest- } \\
\text { Posttest }\end{array}$ & $-14,22222$ & 6,00214 & 1,15511 & $-16,59659$ & $-11,84786$ & $-12,312$ & 26 & 0,000 \\
\hline
\end{tabular}

Berdasarkan hasil hipotesis diperoleh 0,000. Dapat diartikan 0,000 $<0,05$. Maka dapat dinyatakan $\mathrm{H}_{\mathrm{a}}$ diterima karena nilai signifikansinya kurang dari 0,05.

\subsection{Uji Hipotesis Hasil Belajar Siswa}

Uji hipotesis pada penelitian ini menggunakan uji Paired Samples Test. Berikut merupakan Tabel 8. hasil perhitungan uji hipotesis.

Tabel 8. Uji Paired Sampel Test Hasil Belajar

\begin{tabular}{|c|c|c|c|c|c|c|c|c|}
\hline & & & & $\begin{array}{l}\text { 95\% Con } \\
\text { Interval c } \\
\text { Differenc }\end{array}$ & & & & \\
\hline & Mean & $\begin{array}{c}\text { Std. } \\
\text { Deviasi }\end{array}$ & $\begin{array}{l}\text { Std. Error } \\
\text { Mean }\end{array}$ & Lower & Upper & 1 & df & $\begin{array}{l}\text { Sig. (2- } \\
\text { tailed) }\end{array}$ \\
\hline $\begin{array}{l}\text { Pretest- } \\
\text { Posttest }\end{array}$ & $-16,519$ & 8,350 & 1,607 & $-19,822$ & $-13,215$ & $-10,279$ & 26 & 0,000 \\
\hline
\end{tabular}

Berdasarkan hasil hipotesis diperoleh 0,000. Dapat diartikan 0,000 $<0,05$. Maka dapat dinyatakan $\mathrm{H}_{a}$ diterima karena nilai signifikansinya kurang dari 0,05.

\subsubsection{Uji N-Gain Score}

$N$-Gain Score pada penelitian ini digunakan untuk melihat keefektifan media video terhadap minat dan hasil belajar.

\subsection{Uji N-Gain Score Minat Belajar Siswa}

Pada penelitan menggunakan rumus $N$-Gain. Berikut merupakan Tabel 9. data minat belajar belajar pretest, posttest, dan N-Gain Score. 
Tabel 9. Uji N-Gain Score Minat Belajar

\begin{tabular}{cccc}
\hline Responden & Pretest & Posttest & N-Gain Score \\
\hline AF & 38 & 61 & 0,71 \\
AJ & 40 & 65 & 0,83 \\
A & 60 & 70 & 1,00 \\
AAN & 63 & 67 & 0,57 \\
AZD & 43 & 67 & 0,89 \\
CWB & 50 & 60 & 0,50 \\
EAK & 51 & 70 & 1,00 \\
FAR & 46 & 63 & 0,70 \\
IFA & 53 & 70 & 1,00 \\
MKL & 50 & 65 & 0,75 \\
MHRW & 41 & 63 & 0,75 \\
MM & 49 & 60 & 0,52 \\
NNA & 49 & 59 & 0,47 \\
NKL & 50 & 59 & 0,45 \\
NS & 40 & 63 & 0,77 \\
QZK & 61 & 65 & 0,44 \\
DA & 51 & 61 & 0,52 \\
RNQ & 58 & 70 & 1,00 \\
RT & 54 & 61 & 0,43 \\
RFC & 49 & 67 & 0,85 \\
RPA & 51 & 63 & 0,63 \\
RLF & 51 & 65 & 0,73 \\
SS & 47 & 60 & 0,56 \\
NN & 47 & 61 & 0,60 \\
SY & 48 & 63 & 0,68 \\
TPV & 48 & 55 & 0,31 \\
VP & 46 & 65 & 0,79 \\
\hline & & &
\end{tabular}

Pada tabel di atas diketahui $N$-Gain Score pada setiap siswa. Berdasarkan perhitungan $N$-Gain Score secara menyeluruh diperoleh hasil 18,45. Dan dibagi menjadi banyak sampel yakni sebanyak 27 siswa dan diperoleh rata-rata 0,683. Menurut tabel kriteria $N$-Gain Score dapat dikatakan bahwa penggunaan media video pembelajaran efektif terhadap minat belajar siswa kelas III SDN Bumiayu 2 dengan kategori sedang.

\subsection{Uji N-Gain Score Hasil Belajar Siswa}

Pada penelitan menggunakan rumus $N$-Gain. Berikut merupakan Tabel 9. data minat belajar belajar pretest, posttest, dan N-Gain Score.

Tabel 10. Uji N-Gain Score Hasil Belajar

\begin{tabular}{cccc}
\hline Responden & Pretest & Posttest & N-Gain Score \\
\hline AF & 53 & 60 & 0,14 \\
AJ & 60 & 73 & 0,32 \\
A & 53 & 60 & 0,14 \\
AAN & 33 & 60 & 0,40 \\
AZD & 53 & 73 & 0,42 \\
CWB & 60 & 87 & 0,67 \\
EAK & 40 & 73 & 0,55 \\
FAR & 53 & 80 & 0,57 \\
IFA & 67 & 73 & 0,18
\end{tabular}




\begin{tabular}{cccc}
\hline Responden & Pretest & Posttest & $\boldsymbol{N}$-Gain Score \\
\hline MKL & 67 & 73 & 0,18 \\
MHRW & 80 & 87 & 0,35 \\
MM & 53 & 80 & 0,57 \\
NNA & 73 & 87 & 0,51 \\
NKL & 73 & 80 & 0,25 \\
NS & 73 & 87 & 0,51 \\
QZK & 87 & 100 & 1,00 \\
DA & 40 & 60 & 0,33 \\
RNQ & 60 & 73 & 0,32 \\
RT & 67 & 80 & 0,39 \\
RFC & 80 & 93 & 0,65 \\
RPA & 30 & 60 & 0,42 \\
RLF & 40 & 67 & 0,45 \\
SS & 80 & 87 & 0,35 \\
NN & 53 & 73 & 0,42 \\
SY & 60 & 80 & 0,50 \\
TPV & 53 & 67 & 0,29 \\
VP & 73 & 87 & 0,51 \\
\hline
\end{tabular}

Pada tabel di atas diketahui $N$-Gain Score pada setiap siswa. Berdasarkan perhitungan $N$-Gain Score secara menyeluruh diperoleh hasil 11,453. Dan dibagi menjadi banyak sampel yakni sebanyak 27 siswa dan diperoleh rata-rata 0,42. Menurut tabel kriteria $N$-Gain Score dapat dikatakan bahwa penggunaan media video pembelajaran efektif terhadap minat belajar siswa kelas III SDN Bumiayu 2 dengan kategori sedang.

\subsection{Pembahasan}

\subsection{Keefektifan Media Video terhadap Minat Belajar Siswa}

Media video pembelajaran matematika dilakukan di SDN Bumiayu 2 dengan jumlah sampel 27 siswa. Kegiatan pembelajaran dilaksanakan pada tanggal 28 April 2021 sampai dengan 5 Mei 2021. Kegiatan pembelajaran dilakukan 3 pertemuan tiap shift. untuk pertemuan ke-1 siswa melakukan pretest, dan pertemuan ke-2 melaksanakan kegiatan belajar mengajar di kelas, dilanjutkan pertemuan ke-3 melaksanakan posttest. Kelas III dibagi menjadi 2 shift dengan tiap shift sebanyak 14 dan 13 siswa dan dilakukan secara bergantian.

Berdasarkan data pada tabel 1. diketahui bahwa pada pretest nilai minimum sebesar 38 dan untuk nilai maksimum diperoleh siswa sebesar 63. Untuk mean 49,407 dan pada varians 38,789. Sedangkan, pada posttest nilai minimum diperoleh 55 , untuk nilai maksimum diperoleh siswa sebesar 70, dan pada mean 63,629 dan varians 15,088.

Hasil uji normalitas minat belajar siswa kelas III dengan menggunakan uji Shapiro Wilk dengan hasil signifikansi 0,242 untuk pretest. Data berdistribusi normal apabila $>0,05$ sebagai taraf signifikansi. 0,242>0,05 maka data tersebut dinyatakan berdistribusi normal. Sedangkan untuk nilai posttest mendapatkan nilai signifikansi 0,215 . Data berdistribusi normal karena $0,215>0,05$. Dari uji normalitas pretest dan posttest memiliki data yang berdistribusi normal.

Pada hasil uji homogenitas didapatkan nilai signifikansi 0,145 dan memiliki varian homogen karena 0,145 $>0,05$. Pada penelitian ini menggunakan uji Paired Samples Test dengan nilai 0,000 dan taraf signifikansi 0,05. Pada uji Paired Samples Test 0,000<0,005 dalam 
artian $\mathrm{H}_{0}$ ditolak dan $\mathrm{H}_{2}$ diterima. Hal ini berarti terdapat perbedaan minat belajar siswa dengan menggunakan media video pembelajaran.

Pada penelitian ini memperoleh peningkatan saat melakukan pretest 49,40 menjadi 63,62 pada saat melakukan posttest. Dengan menguji keefektifan peneliti menggunakan NGain Score dan didapatkan rata-rata 0,683. Berdasarkan peningkatan saat posttest dan dari tabel kriteria $\mathrm{N}$-Gain Score dapat dikatakan bahwa penggunaan media video pembelajaran efektif terhadap minat belajar dengan kategori sedang. Hasil penelitian diperkuat dengan adanya penelitian dari Rahmayanti (2016) dengan hasil 2,060 menjadi 7,931 maka dapat dikatakan bahwa media video efektif terhadap minat belajar.

\subsection{Keefektifan Media Video terhadap Hasil Belajar Siswa}

Media video pembelajaran matematika dilakukan di SDN Bumiayu 2 dengan jumlah sampel 27 siswa. Kegiatan pembelajaran dilaksanakan pada tanggal 28 April 2021 sampai dengan 5 Mei 2021. Kegiatan pembelajaran dilakukan 3 pertemuan tiap shift. untuk pertemuan ke-1 siswa melakukan pretest, dan pertemuan ke-2 melaksanakan kegiatan belajar mengajar di kelas, dilanjutkan pertemuan ke-3 melaksanakan posttest. Kelas III dibagi menjadi 2 shift dengan tiap shift sebanyak 14 dan 13 siswa dan dilakukan secara bergantian.

Berdasarkan data pada tabel 2. diketahui bahwa pada pretest nilai minimum sebesar 30 dan untuk nilai maksimum diperoleh siswa sebesar 87 . Untuk mean 59,787 dan pada varians 227,795 . Sedangkan, pada posttest nilai minimum diperoleh 60 , untuk nilai maksimum diperoleh siswa sebesar 100, dan pada mean 76,29 dan varians 122,063.

Hasil uji normalitas hasil belajar siswa kelas III dengan menggunakan uji Shapiro Wilk dengan hasil signifikansi 0,349 untuk pretest. Data berdistribusi normal apabila $>0,05$ sebagai taraf signifikansi. 0,349>0,05 maka data tersebut dinyatakan berdistribusi normal. Sedangkan untuk nilai posttest mendapatkan nilai signifikansi 0,085. Data berdistribusi normal karena $0,085>0,05$. Dari uji normalitas pretest dan posttest memiliki data yang berdistribusi normal.

Pada hasil uji homogenitas didapatkan nilai signifikansi 0,149 dan memiliki varian homogen karena 0,149 > 0,05. Pada penelitian ini menggunakan uji Paired Samples Test dengan nilai 0,000 dan taraf signifikansi 0,05. Pada uji Paired Samples Test 0,000 0,005 dalam artian $\mathrm{H}_{0}$ ditolak dan $\mathrm{H}_{2}$ diterima. Hal ini berarti terdapat perbedaan hasil belajar siswa dengan menggunakan media video pembelajaran.

Pada penelitian ini memperoleh peningkatan saat melakukan pretest 59,78 menjadi 76,29 pada saat melakukan posttest. Dengan menguji keefektifan peneliti menggunakan NGain Score dan didapatkan rata-rata 0,42. Berdasarkan peningkatan saat posttest dan dari tabel kriteria N-Gain Score dapat dikatakan bahwa penggunaan media video pembelajaran efektif terhadap hasil belajar dengan kategori sedang. Hasil penelitian diperkuat dengan adanya penelitian dari Rahmayanti (2016) dengan hasil 2,056 menjadi 5,603 maka dapat dikatakan bahwa media video efektif terhadap hasil belajar.

\section{Simpulan}

Media video pembelajaran yang diterapkan memiliki tingkat keefektifan sedang terhadap minat belajar siswa. Diketahui dengan hasil rata-rata mengalami peningkatan pada saat melakukan pretest dengan nilai 49,40 menjadi 63,62 pada saat posttest dan pada uji $N$ - 
Gain Score yang memiliki rata-rata 0,683 pada minat belajar siswa kelas III SDN Bumiayu 2. Hasil belajar pada siswa kelas III SDN Bumiayu 2 memiliki keefektifan yang sedang saat menggunakan media video pembelajaran, hal ini dilihat dari hasil rata-rata yang mengalami peningkatan pada saat melakukan pretest 59,78 menjadi 76,29 saat melakukan posttest. Untuk uji $N$-Gain Score memiliki rata-rata 0,42 pada hasil belajar siswa kelas III.

\section{Daftar Rujukan}

Amir, A. (2016). Penggunaan Media Gambar Dalam Pembelajaran Matematika. Jurnal Eksakta. 2(1). 34-40.

Asyari, I., Saputra. S. Y., \& Amelia. D. J. (2018). Pembelajaran Tematik Integratif pada Kurikulum 2013 di Kelas Rendah SD Muhammadiyah 07 Wajak. JINoP (Jurnal Inovasi Pembelajaran). 4(1). 35-46.

Hakim, L. (2016). Pemerataan akses pendidikan bagi rakyat sesuai dengan amanat Undang-Undang Nomor 20 Tahun 2003 tentang Sistem Pendidikan Nasional. EduTech: Jurnal Ilmu Pendidikan Dan Ilmu Sosial, 2(1).

Rahmayanti, A. (2016). Keefektifan Media Video Terhadap Minat dan Hasil Belajar IPA Kelas V SD Negeri Kepandean 03 Kecamatan Dukuhturi Kabupaten Tegal. Skripsi diterbitkan. Semarang: Fakultas Ilmu Pendidikan.

Riwahyudin, A. (2015). Pengaruh Sikap Siswa dan Minat Belajar Siswa Terhadap Hasil Belajar IPA Siswa Kelas V Sekolah Dasar di Kabupaten Lamandau. Jurnal Pendidikan Dasar. 6(1). 11-23. https://doi.org/10.21009/JPD.061.02

Salsabila, A., \& Puspitasari. (2020). Faktor-faktor yang mempengaruhi Prestasi Belajar Siswa Sekolah Dasar. Pandawa: Jurnal Pendidikan dan Dakwah. 2(2). 278-288. https://doi.org/10.36088/pandawa.v2i2.800

Ulya, H. (2017). Permainan Tradisional Sebagai Media Dalam Pembelajaran Matematika. Prosiding Seminar Nasional Pendidikan. 371-376.

Wisada,P. D., \& Sudarma, I. K. (2019). Pengembanagan Media Video Pembelakaran Berorientasi Pendidikan Karakter. Journal of Education Technology. 3(3).140-146. http://dx.doi.org/10. 23887/jet.v3i3.2175 